\title{
Uudne metafoorne keelend: kas laen või diakroonilise arengu tulemus?
}

\author{
KATRE ÕIM \\ Tallinna Ülikool \\ ASTA ÕIM \\ Eesti Kirjandusmuuseum \\ PIRKKO MUIKKU-WERNER \\ Ida-Soome Ülikool
}

Ülevaade. Viimasel paarikümnel aastal on eesti kirjakeele sõnavara keeleväliste tegurite koostoimel kiiresti arenenud, muutusi on märgata ka argikeeles. Artiklis selgitatakse praegusajal väga sageli kasutatavate uudsete metafoorsete üksiksõnade, sõnavormide ja sõnaühendite tähendusi, näidatakse nende tähenduste konstrueerimise kulgu ja tähtsust leksikaliseerumisel ning leksikaalsemantilisi seoseid soome lekseemidega. Kõiki käsitletavaid keelendeid iseloomustab ühelt poolt mittekonventsionaalsus, teiselt poolt toetumine inimlikule konventsionaalsele mõistesüsteemile ja seeläbi seotus olemasolevate leksikoniüksustega. Viimastega võrreldes on uudsete metafoorsete keelendite tähenduses erinevusi, mis võivad olla markeeritud ka leksikaalselt ja/või morfosüntaktiliselt. Semantilises plaanis on ilmne, et 1) tänapäeva eesti keele polüseemiline üksiksõna avardub semantiliselt; 2) polüseemilise üksiksõna ümber tekkiv fraas on selle üksiksõnaga võrreldes semantiliselt kitsam; 3) fraseologism ja uudne metafoorne sõnaühend on üksteise suhtes leksikaalsemantilised variandid. Nende 
jm tegurite mõjul on artiklis käsitletavad eesti uudsed metafoorsed keelendid sotsialiseerumisjärgus.

Võtmesõnad: kognitiivne keeleteadus; semantika; mõistemetafoor; uudne metafoorne keelend; eesti keel; soome keel

\section{Sissejuhatus}

Eesti kirjalikes avalikes tekstides kasutatakse praegu väga sageli sõnu, millel on vasted soome keeles: broiler - sm broileri; kummitempel kumileimasin; kuum - kuuma; laud on puhas, lauda puhtaks lööma puhdistaa pöytä, syödä pöytä puhtaaksi; nael kirstu - viimeinen naula arkkuun; puudel - villakoira; pöördes - pyörteessä, pyörryksissä; rong on läinud, rongilt maas - jäädä junasta; siga- - sika-; tempel otsa ees - leima otsassa; viimase peal - viimeisen päälle. Meie eesmärk on selgitada, mida need üksiksõnad, sõnavormid ja sõnaühendid tähendavad, mis nende tähendusi motiveerib, millised on nende seosed eesti ja soome keeles olemasolevate leksikoniüksustega ja eeldused saada ise leksikoniüksuseks - sõnaga näidata tähenduse konstrueerimise kulgu ja tähtsust nende leksikaliseerumisel. Kasutame artiklis toetuspunkte kognitiivsest metafooriteooriast ja soome keelest, osutame metafoorsete keelendite mõistmise osalisele süsteemsusele ning keeles tihti avalduvatele ja eestisoome kultuuriruumile iseloomulikele mõistemustritele.

Analüüsitavad eesti keelendid pärinevad 2011.-2012. a ajalehtedest-ajakirjadest jm trükiväljaannetest, internetist (kasutasime Google’i otsimootorit) $^{1}$; nende soome vasted leidsime E. Kari (NK 1993) ja P. Muikku-Werneri, J. H. Jantuneni, O. Kokko (SS 2008) tänapäeva soome keele fraseoloogiasõnaraamatutest, "Kielitoimiston sanakirjast" (MOT), mõnede reservatsioonidega ka "Urbaani sanakirjast" (US) ning internetist. Kuigi lihtsalt mõistetavad uudsed metafoorsed keelendid on tarbetekstides väga sagedased (vt nt Croft \& Cruse 2010: 204), ei pruugi see vastavates korpustes nii olla (Steen jt 2010: 47). Näiteks

\footnotetext{
1 Suurem osa sellest materjalist on kaasatud kogumikku "Komistusi metafooridega" (A. Õim 2011).
} 
EKI tekstikorpuse rubriikides Ajalehed, Ajakirjad jm väljaanded, Ilukirjandus (1990-2011) leidub vaid üksikuid näiteid: aktsiaturud tugevasti rallisid.

Lähtusime materjalivalikul sellest, et nende keelendite kasutamine metafoorses tähenduses on eesti keeles 1) Google’i järgi sage ja 2) mittekonventsionaalne - seda ei ole fikseeritud "Õigekeelsussõnaraamatu" (ÕS) või "Eesti keele seletava sõnaraamatu” (EKSS) veebiversioonis ei leksikoniüksuse, põhi- ega alltähenduse tasandil (vt ka Steen jt 2010: 47) ning 3) nad on leksikaalsemantiliselt struktuurilt väga lähedased soome lekseemidele.

Artiklis käsitletavate keelendite levik ja kasutusseosed on soome ja eesti keeles üsna erinevad, kuid suuremat osa neist ühendab tarbestiil. Soome materjali hulgas on eri vanusega keeleüksusi, mõned, näiteks kumileimasin 'kummitempel', syödä pöytä puhtaaksi 'lauda tühjaks sööma', sisalduvad 1970-ndatel ilmunud sõnaraamatutes ja tunduvad tänapäeval isegi arhailisevõitu. Pihtiputaan mummo 'lihtsa mõtlemisega vanem naine' ja sika- 'väga, kangesti, kõvasti, äärmiselt, hirmsasti' idiomaatiline kasutus on uudne, kuigi sellest on jälgi vähemalt ühes sõnaraamatus. Pihtiputaan mummo stiil on naljatlev, sõna sika- kasutatakse või on kasutatud pigem noorte kõnekeeles ja vähem informatiivsetes tekstides. Erandlik on sylikoira, mida tähenduses 'keegi, kes püüab kõigile meeldida’ sõnaraamatutest ei leia (käsitleme seda allpool seoses lekseemiga puudel), küll aga internetist: Media - Soinin sylikoira? Tõenäoliselt on tegu tõlkelaenuga inglise keelest, kus lap dog tähendab 'keegi, kes tahab meeldida'. Viimasel ajal on tänapäeva soome keelde tulnud rohkesti sedalaadi laene: apina selässä 'probleem', rampa ankka 'tegutsemisvõimetu isik, tihti poliitik', kuid tihti jääb nende tähendus arusaamatuks (Penttilä \& Muikku-Werner 2012).

Kas tegemist on soome laenudega eesti keeles? Kuigi fraseologismid on väga altid keelte vahel liikuma, oleks ebatavaline, kui tänapäeva soome keeles vähesagedasteks ja väga kinnistunuks muutunud fraseologismid oleks alles nüüd eesti keelde laenatud. Allpool ei kirjelda me mitte laenusuhteid, vaid keelendite paralleelset kasutamist. Artikli fookusest jäävad 
välja nii eesti keelendite võimalik omakeelne või laenuline päritolu kui ka uued mõistemetafoorid ja ainukordne metafoorne keelekasutus.

\section{Uudsete metafoorsete keelendite olemus ja kasutamine}

Uuskeelendi tunnuseid on uurijad nimetanud kuni kaheksa, kuid üksmeelsed ollakse selles, et nad on uudsed, konkreetse keele sõnavara osa, kõnelejaskonnas mõistetavad ning kirjalikus tekstis vähemalt kolmel korral kasutatud. Saksa keeles on eristatud neolekseeme (uudismoodustised - tuletised, liitsõnad, abreviatuurid), neosemantlisi keelendeid (uued mittemetafoorsed leksikaalsemantilised variandid ja metafoorsed semantilised variandid), uuslaene ja uusi kontekstisidusaid sõnaühendeid. (Bilibin 2009b: 8.) Loetletuist huvitavad meid liitsõnalised uudismoodustised ja metafoorsed semantilised variandid, mida nimetame üldistavalt uudseteks metafoorseteks keelenditeks. Eelistame seda terminitele uudismetafoor, uusmetafoor vmt, vrd novel metaphor, ja peame sellega silmas kujundlikus, s.o metafoorses, metonüümilises jmt tähenduses üksiksõnu, sõnavorme ja fraase (vt M. Erelt jt 2003).

\subsection{Uuskeelendite tekkimise põhjustest ja uurimisest}

Inimühiskonna arenedes muutub ka keel, esmajoones mõistagi selle sõnavara. Viimasel paarikümnel aastal on eesti keele sõnavara täienenud ja mõnevõrra ka teisenenud eriti kiiresti tänu keelevälistele teguritele, s.o poliitilistele, majanduslikele ja kultuurilistele muutustele. Keelendamist on nõudnud arvukad uued mõisted, pärast Eesti ühinemist Euroopa Liiduga on meie keelde tekkinud nn nomenklatuurne eurosõnavara. Paljud uued terminid on omaks võetud, näiteks on EKI sõnauselt lühikese aja jooksul kasutusse võetud taristu infrastruktuuri tähenduses.

Keel elab ja areneb edasi siis, kui selle kõnelejaskonnal on keeleloome võime, s.t keelt suudetakse vajaduse järgi täiendada mis tahes tasandil, eriti luua juurde uusi keelendeid. Sõnavara arenemise paindlikkuse 
oluline eeldus on keele seesmised mehhanismid, mis tagavad, et keel on suuteline kaasa minema areneva ühiskonna vajadustega. Alati ei olegi otsest tarvidust uue sõna või sõnaühendi järele, vaid olemasolevate väljendusvõimaluste kõrvale ja asemele otsitakse hoopis uusi, täpsemaid, isikupäraseid, mõnikord ka epateerivaid. Viimasel kümnendil on kasvanud huvi sõnavaramuutuste uurimise vastu just neis riikides, mida on otseselt mõjutanud põhjalikud poliitilised ja majanduslikud ümberkorraldused Euroopas. Need muutused kajastuvad ootuspäraselt keeles, eriti selle poliitilises sõnavaras (vt Weinrich 2002; Brandstetter 1995). Uute üksik- ja liitsõnade, sõnaühendite, metafoorsete keelendite juurdevool on tinginud neoloogia ja neograafia eraldumise iseseisvateks leksikoloogiaharudeks (vt Senko 2007; Gatsalova 2005; Popova 2005; Skuratov 2006). Uurimuste rohkus torkab silma just germanistikas. Neoloogia raames on uuritud inglise ja saksa keele vastastikust mõjutamist (vt Ammon 2002), käsitletud nii sõnavaramuutusi tervikuna (Bilibin 2009a; Katajeva 2003; Klotško 2006) kui ka üksikprobleeme - uusfraseoloogiat EL ametlike dokumentide keeles (vt Greciano 2004), mõistemetafoore ja metafoorimudeleid meediakeeles (vt Schäffner 1995; Zinken \& Bolotova 2006; Tšudinov 2001). Eestis on enim uurimishuvi pakkunud meedia, eeskätt päeva- ja nädalalehtede keelekasutus (vt Kasik 2003; Rohtlaan 2006), poliitiline sõnavara (vt Kukk 2001) ja eurokeele korraldamine. EKI sarja "Keelenõuanne soovitab” (1-4) väljaannetes moodustavad märkimisväärse osa soovitused üksiksõnade kasutamiseks.

\subsection{Uudsete metafoorsete keelenditega seotud rakenduslikke ja teoreetilisi probleeme}

Keele sõnavara arendamisel ei teki vastuolusid, kui see käib läbi keelekogukonnale omaste mõistesüsteemide. Näiteks võõrkeelest mugandatud metafoorne keeleüksus võib olla märk keele avatusest, arenemisest ja me ei peaks seda tingimata tõrjuma isegi kui tundub et "meil ei ole neid sõnu tegelikult vaja - mõisted, mida nad tähistama on tulnud, on meile ammu tuttavad ja sõnad nende kohta täiesti olemas" (Raadik 2008: 46). 
Iseasi, mida missuguses tekstis ja kui sageli kasutada. Samuti poleks õige mööda vaadata (hetke)normingust hälbivaist keelendeist, mida loomulikus suhtluses ohtralt kasutatakse ja mida on keelekorraldajail raske suunata. Mõnikord paistab kirjakeeles välja ebalev suhtumine nii uudsetesse kui ka konventsionaalsetesse metafoorsetesse keelenditesse, mida kasutatakse jutumärkides või koos üldlaiendiga nii öelda, rõhutatakse vastuoluliselt (vrd sõna otseses mõttes ja literally inglise $\mathrm{k}^{2}$ ). Pole selge, kas niimoodi markeeritakse keelendite metafoorsust ${ }^{3}$, argikeelsust vm:

(1) “mälukaotus" kooli alguse puhul: noored tarbivad alkoholi; sõna otseses mõttes puudutab kaugküttevõrkude ühendamine rohkem kui pooli; stress on tihtipeale lausa vajalik, et inimene nii-öelda maapeale tagasi tuua.

Keele mitmekesisus ja arenemine on loomulik; see, millest saab kirjakeele osa, selgub aja jooksul.

Mõistagi on konkreetsete keelemuutuste uurimisel oluline leida uudse nähtuse seletamiseks sobivaimad vahendid. Kujundkõne uuritakse tänapäeval väga sageli kognitiivses võtmes, mille järgi ei sõltu keeleline kategoriseerimine mitte ainult maailmas eksisteerivate tunnuste nimetamisest, vaid ka meie maailma tajumise metafoorsest ja metonüümilisest struktureerimisest. Kuna sõna ei omanda uusi tähendusi mitte juhuslikult, vaid läbi kognitiivse struktureerimise, on selle arvukad sünkroonilised tähendused harilikult motiveeritud moel ka seotud. Oluline on diakrooniline aspekt - üksteisega seotud sõnade arengut uurides peaks olema võimalik näha, milliseid süsteemseid struktuure meie kognitiivne süsteem olulistele valdkondadele enamasti annab. (Sweetser 1991: 9) Siinkohal võib küsida, kas näiteks konventsionaalsete väljendite ilmne süsteemsus võib olla ajaloolise arengu tulemus, mis ei mõjuta

2 Vt ka teose "Metafoorid, mille järgi me elame" tõlke eessõna M. Lotmanilt (2011: 13).

3 Sarnased küsimused tekivad näiteks fraasi osiste kokkukirjutuse juures. K. Habichti ja P. Penjami (2007: 55, 63) andmeil kirjutab tavakeelekasutaja kaassõna eelneva nimi- või asesõnaga sageli kokku ja põhjendab seda ise mh nii, et tajub kaassõnafraasi enam või vähem terviklikuna, iseseisvat (ülekandelist) tähendust omavana. 
seda, kuidas inimesed tänapäeval mõtlevad ja keelt kasutavad? Kas erinevate sõnade ja väljendite süsteemsus võib seonduda polüseemiaga ja mitte mõistemetafooriga? (Gibbs 2007: 7, 8.) E. Sweetser (1991) on inglise keele põhjal näidanud, et a) leksikaalse tähenduse polüseemia mustrite, b) tähendusmuutuse ajalooliste mallide ning c) konjugeeritud ja tingimuslausete interpreteerimisvõimaluste aluseks võib olla üks ja sama kognitiivne (metafoorne) struktuur. (Sweetser 1991: 9, 22 jj.) Metafoorsete keelendite reaalajas mõistmisega seonduvad küsimused kontseptuaalsest integratsioonist ja konteksti rollist selles (vt nt Croft \& Cruse: 2010: 207, 209). Ja lõpuks: kas ainult keelelisest tõendusmaterjalist piisab väitmaks, et mõistemetafoore kasutatakse pidevalt ja automaatselt pingutuseta ja mitteteadlikult (vrd Lakoff 2006: 213)? R. Gibbs jpt arvavad, et mitte. (Gibbs 2007: 7.) Ometi on uudseid metafoorseid keelendeid raske eirata, sest "Many colloquial expressions do not .. belong to a separate category of linguistic entity (the wastebasket!) apart from both literal and other types of figurative language but reflect various linguistic and conceptual knowledge that is used repeatedly when people speak about their everyday experiences" (Gibbs 2002: 318).

\section{Uudsete metafoorsete keelendite mõistmismehhanisme}

Kognitiivse metafooriteooria järgi on inimliku argireaalsuse kujundamisel kesksel kohal metafoorselt liigendatud mõistete süsteem ja see peegeldub keeles (Lakoff \& Johnson 2011: 37 jj). Kuigi selles mõistesüsteemis leidub lõputult mõistemetafoore, on vähesed neist erilised. Kõige põhilisemad mõistemetafoorid on mõisteliselt vältimatud ja konventsionaalsed, näiteks nagu SURM ON LAHKUMINE. Mõistetasandil tähendab konventsionaalsus seda, et mõistemetafoor on automaatne, sundimatu ja kehtib keelekogukonnas üldiselt kui mõtlemisviis. Keeletasandil on oluline, kui paljude argikeelendite aluseks mõistemetafoor on. Suhteliselt väheste põhiliste mõistemetafooride kombineerimise tulemus on lõputud metafoorsed keelendid. (Lakoff \& Turner 1989: 51-56.) "Keelelist 
mõistmist" uurides ja seletades tuleks tingimata mõelda, kummal tasandil seda tehakse - kas mõiste- või keeletasandil. (Gibbs 2007: 9.)

Loomingulised mõistemetafoorid, näiteks nagu ARMASTUS ON ÜHINE KUNSTITÖÖ, mida ei teki ilmselt kuigi sageli, konventsionaalsesse mõistesüsteemi ei kuulu (Lakoff \& Johnson 2011: 175).

Olenemata sellest, kui tavalised on uudsed metafoorsed keelendid, kasutatakse neid harvem kui konventsionaalseid, mis ilmnevad enamikus lausetes. Meie igapäevane metafoorisüsteem, mida me nii tavapäraste mõistete nagu AEG, SEISUND, MUUTUS, PÕHJUSTAMINE, EESMÄRK jne mõistmiseks kasutame, on pidevalt aktiivne. Me rakendame seda maksimaalselt mõistmaks uudset metafoorset keelekasutust. G. Lakoff ja M. Turner (1989) on poeetilisi metafoore uurides välja toonud kolm põhilist mehhanismi metafoorsete väljendite interpreteerimiseks uudsetena: konventsionaalsete metafooride laiendused, üldtasandi metafoorid ja imagometafoorid (ingl image-metaphor). Näiteks võib liitsõna konnatiik tähenduses 'inimtegevuse paigalseis' olla mõistemetafooride MITTETEGUTSEMINE ON SEISAK, STAGNEERUNUD INIMKOOSLUS ON SEISEV VEEKOGU manifestatsioon, millesse on ühelt poolt kaasatud sündmused ja teiselt poolt ruum. Siin ei ole mängus muud kui konventsionaalsete metafooride süsteem, tavaline teadmusstruktuur, mille on esile kutsunud keelendi konventsionaalne tähendus, ja sellel rajanevad metafoorsed järeldused. Vajalike interpretatsioonideni jõudmiseks on tarvis vaid konventsionaalsete metafooride struktuuri ja keelendi esile kutsutud teadmusstruktuuri. Konventsionaalset ülekannet rakendatakse teadmusstruktuuril, mis annab sobivad järeldused. Spetsiaalseid mehhanisme siin vaja ei ole. (Lakoff 2006: 223, 224.) Paljusid uudseid metafoorseid keelendeid võidakse siiski mõista ka ilma, et olemasolevad mõistemetafoorid seda mõjutaks. Introspektiivselt võib tunduda, et uudsed metafoorsed keelendid kajastavad tavalisi metafoorseid mõisteid inimese pikaajalises mälus. (Gibbs 2002: 263, 264.)

G. Lakoff ja M. Johnson (2011: 87) on metafoorse liigendamise osalisusest rääkides eritlenud kolme eri sorti kujundlikke metafoore: 1) metafoori juba kasutusel olevate osade laiendused, 2) sünkroonsel 
tasandil otsetähenduslike metafooride kasutamata osade rakendamine, 3) uudsed metafoorid, mis ei liigenda mingit osa meie harjumuspärasest mõistesüsteemist, vaid võimaldavad mõelda mõnest asjast täiesti uut moodi. Laiendades argiste mõistemetafooride harilikult kasutatavaid osi või rakendades nende tavaliselt kasutamata jäävaid elemente ei teki küll midagi päris uut, kuid see kajastab metafoorset mõtlemist (Gibbs 2002: 157).

Uut metafoorset keelt juhib üldistamine (Lakoff 2006: 193; Lakoffi selgitav näide on LOVE IS A JOURNEY). Näiteks mõistemetafoori STAGNEERUNUD INIMKOOSLUS ON SEISEV VEEKOGU iseloomustab üldistamine kahes mõttes: polüseemia üldistamine, s.o keeleliste väljendite seotud tähenduste üldistamine, nt väike, suletud, eraldatud, paigal seisma, seisev vesi, hägune, läbipaistmatu jne, ja järelduslik, s.o eri mõistealade vaheliste järelduste üldistamine. Nimetatud ülekande olemasolu aitab seletada, miks võidakse kasutada nt 1) loodusvaldkonna sõnu inimühiskonna kirjeldamiseks ja 2) looduse kohta käivaid järeldusmalle ka inimühiskonna puhul, vrd on löönud Eesti politilise konnatiigi korralikult lainetama ja Vaalitulos toi poreita Tampereen ankkalammikkoon (soome ankkalammikko tähendus on piiratud soomerootslaste väikeste suletud kooslustega). Sellised valdkondadevahelised sõnade ja järeldusmallide paarid kinnitavad omakorda ülekannete eksisteerimist. (Lakoff 2006: 188, 193.) Üldise tasandi metafooridel puudub kindel allik- ja sihtala ning kindel hulk olemeid, mida ülekandes täpsustataks. Üldise tasandi metafoor GENEERILINE ON SPETSIIFILINE kannab teadmised konkreetsetelt valdkondadelt palju üldisematele sündmustele: ühe spetsiifilise tasandi skeemi või situatsiooni kui tahes suurele hulgale paralleelsetele spetsiifilise tasandi skeemidele. Viimastel on sama üldise tasandi struktuur mis allikala skeemil. Selles seisneb geneerilise spetsiifilise abil mõistmise üldine mehhanism. Spetsiifilise tasandi skeemid on konkreetsed, hästi ette kujutatavad, seotud meie argikogemustega ja jäävad hästi meelde. Geneerilise tasandi skeemide üldistusvõime on rakendatav väga erinevatel juhtudel. (Lakoff \& Turner 1989: 80, 162 jj; Gibbs 2002: 313 jj; vt ka eesti keeles Krikmann 2003: 73 jj.) 
Mitte kõik mõistemetafoorid ei kanna mõistestruktuure üle teistele mõistestruktuuridele. Selliste metafooride kõrval, mis korraldavad teadvustamatult ja automaatselt meie tavapärast maailma mõistmist, tuleb (otsetähenduses) tekstides sageli ette lühiajalisi imagometafoore, mis kajastavad kujutluste ülekannet: Vaikselt libistad elu$^{4}$, vrd libistama 'mööda siledat, libedat või veerjat pinda liikuma panema', '(õlut) jooma': Pirogovi platsil oli paar seltskonda ôlut libistamas (EKSS). Kujutluse struktuur sisaldab nii osa-terviku kui ka atribuudi struktuuri, s.o värv, valguse intensiivsus, väline kuju, kumerus, sündmuste üldine vorm: pidev või mittepidev, lõpetatud või lõpetamata, korduv või mittekorduv, lühi- või pikaajaline. Just sõnad ajendavad meid tegema mõistetasandil ülekannet ühelt konventsionaalselt kujutluselt teisele. Samas peetakse imagometafoore ühekordseteks - kujutluste ülekannet piirab nende detailiderohkus, samuti ei sisalda nad sedavõrd rikkalike teadmiste ülekannet ega järelduste struktuuri kui skeemkujutluste või mõistelised ülekanded. Ja tavaliselt neid kogemuste mõistestamistel ei kasutata. (Lakoff \& Turner 1989: 89-91; Gibbs 2002: 259.) Seetõttu jäävad imagometafoorid väljapoole meie huvi.

Niisiis kasutavad uudsed metafoorsed keelendid suure tõenäosusega meie metafoorselt liigendatud mõistete süsteemi, rajanevad sellel ja esinevad harva sellest sõltumatult (Lakoff 2006: 213). Inimlikus argitunnetuses olulised metafoorsed teadmised põhimõistetest ajendavad meid sama hästi kasutama ning mõistma nii idiomaatilisi, mitteidiomaatilisi kui ka uudseid metafoorseid keelendeid (vt Gibbs 2002: 318; Krikmann 1999). Olemasoleva stabiilse vastavuse aktiveerimine mõistealade mõistete vahel (vt Lakoff \& Johnson 1999: 149) aitab kaasa uudsete metafoorsete keelendite leksikaliseerumisele, mis omakorda kinnitab püsikindla ülekande olemasolu.

4 ... päikse käes sillerdab vaht. / Juurde enam ei tooda, / kuigi küsisid kaht (K. M. Sinijärv, Postimees 10.9.2011). 


\section{Uudsete metafoorsete keelendite mõistestusi ja semantilisi seoseid}

Kõigile allpool analüüsitavatele uudsetele metafoorsetele keelenditele on iseloomulikud semantilised seosed eesti keeles olemasolevate leksikoniüksustega. Viimastega võrreldes on uudsete keelendite tähenduses märgata erinevusi - semantilist laienemist või kitsenemist, mis võib olla markeeritud ka leksikaalselt ja/või morfosüntaktiliselt. Artiklis käsitletavate uudsete metafoorsete keelendite jagunemine mõistestuste ja semantiliste seoste järgi on esitatud tabelis 1 . Allpool selgitame tabelis 1 esitatut võimalike mõistestuste kaupa.

TABEL 1. Uudsete metafoorsete keelendite mõistestus ja semantilised seosed

\begin{tabular}{|l|l|l|l|}
\hline \multirow{2}{*}{ mõistestusviis } & \multirow{2}{*}{$\begin{array}{l}\text { metafoorsed } \\
\text { üksiksõnad, } \\
\text { sõnavormid }\end{array}$} & \multicolumn{2}{|c|}{$\begin{array}{c}\text { metafoorsed sõnaühendid, } \\
\text { mis on semantiliselt seotud }\end{array}$} \\
\cline { 3 - 4 } & $\begin{array}{l}\text { poliuseemiliste } \\
\text { üksiksõnadega }\end{array}$ & fraseologismidega \\
\hline $\begin{array}{l}\text { laiendatakse } \\
\text { metafoori kasutusel } \\
\text { olevaid osi }\end{array}$ & $\begin{array}{l}\text { kuum, siga, } \\
\text { pöördes }\end{array}$ & kummitempel & $\begin{array}{l}\text { lauda puhtaks lööma, } \\
\text { laud on puhas, nael } \\
\text { kirstu, tempel otsa ees }\end{array}$ \\
\hline $\begin{array}{l}\text { rakendatakse } \\
\text { metafoori } \\
\text { kasutamata osi }\end{array}$ & $\begin{array}{l}\text { puudel, } \\
\text { broiler }\end{array}$ & $\begin{array}{l}\text { rong on läinud, } \\
\text { rongilt maas }\end{array}$ & viimase peal \\
\hline
\end{tabular}

\subsection{Metafoori kasutusel olevate osade laiendused}

\subsubsection{Metafoorsed üksiksõnad ja sõnavormid}

Kuum. Soojust kui keha füüsikalist omadust suhestatakse tavapäraselt emotsioonide valdkonnaga. Nii mõistetakse ja väljendatakse tavalisest, normist intensiivsemaid tundeid (2) või tegevusi, millega kaasnevad emotsioonid (3).

(2) kuum armastus; Kuumaa rakkautta Portugalin taivaan alla, vrd soojad tunded; tulises vihas; Mul on sinu tuleku üle tuline heameel.

(3) kuum võitlus (EKSS); Kupittaan kuuma taistelu. 
Uudne paistab olevat see, et TEMPERATUURI allikalast toimub ülekanne sihtalale, mille puhul ei ole tähtsad mitte niivõrd ägedad emotsioonid kui millegi aktuaalsus, seega AKTUAALNE, TÄHTIS või KIIRET LAHENDUST NÕUDEV ON SOE, KUUM (4).

(4) Jalgpalli endised staarid on Indias kuum kaup; Dinosaurusten munista on tullut Kiinassa kuumaa tavaraa; kuum meelelahutusportaal; kuuma vihje 'kiiduväärt, ekstraklassi, priima nõuanne' (NK); Japanin kuuma kysymys - kuka haluaa käynnistää ydinvoimalan?; vrd Sõjakäigud lõunasse olid ju kõige põletavamad uudised (EKSS); Työvoiman saanti polttava ongelma; Kelle poole pöörduda põletavas rahahädas? (EKSS); Hoiab probleemi soojana.

Vrd ka AKTIIVNe on SOE, KUUM (5) ja VAIELDAV või EBASEADUSLIK ON KUUM, VALUSALT PÕLETAV (6).

(5) Vallavanem hoiab arstile kohta soojas; Aus teeb kaasa jäärajasõidu võistlustel, et n.ö kätt soojas hoida.

(6) tippkohtumisel, kus kuuma kartulina on menüüs ka euroala ühised võlakirjad; tutkimus- ja kehitystyö on kansainvälisesti kuuma peruna (SS); Kirpputorien pitäjillä ei ole käytännön resursseja erottaa kuumaa tavaraa (SS).

Eesti keeles moodustatakse nimisõnaga siga tihti vahetult tekstis liitomadussõnu. Substantiivse täiendosaga liitadjektiivides täpsustab täiendosa mh ka põhisõna omaduse määra (EKG I: 558). Täiendosa siganäitabki, et see on ebatavaline, üle normi, näiteks nagu sigalahe tähenduses 'väga lahe, hulltore, vaimustav, hiilgav, oivaline, võrratu' (8).

(7) [raamat] "Sigalahe suvi"; sigalahe mees; Õues on sigalahe olla.

Võrdlus seaga on siin kaudne, kuigi selliste keelendite mõistmisel ei saa välistada mõistemetafoori EBANORMAALNE ON LOOMALIK toimimist, $\operatorname{vrd}(8)$.

(8) joob magab kui siga; paks kui aiasiga; nagu siga poris; on elänyt kuin sika pellossa; üks siga-inimene (Wiedemann); mies on täysi sika. 
Mõnevõrra ootamatu on, et uudsete metafoorsete liitsõnade puhul on siga- tähenduses sisalduv negatiivne hinnang mahenenud ja see intensiivistab põhisõna tähendust, vrd Naurattaa ihan sikana, Kannettava syö paristoja ihan sikana (SS). Tõenäoliselt toimib nende spontaansete liitsõnade täiendosa prefiksilaadselt (vt EKG I: 559), põhiosa semantika paistab olevat üsna piiramatu ja liitomadussõnade seeria seega avatud:

(9) sikahieno $^{5} \sim$ hyvä $\sim$ siisti (SS); sigaraske $\sim$ kerge $\sim$ kallis $\sim$ odavalt $\sim$ kiire $\sim$ kiirelt $\sim$ aeglane.

Metafoorse keelendi pöördes mõistmine rajaneb teadmisel, et inimkeha normaalasendis ümber oma keskpunkti ei pöördu. Pööramise tulemus on muudetud, tavapärasest erinev asend: Poiss on saltopöördes. Olenevalt määrsõnalaadselt kasutatava pöördes tähendustest võivad selle mõistmise aluseks olla mõnevõrra erinevad mõistemetafoorid. Kui lähtuda sellest, et stabiilne sirgjooneline liikumine toimub enamasti otse, siis tähendab pööre objekti asendi- või suunamuutust ja kaasnev ebastabiilsus muutusi, arenguhüpet. Nii võidakse iseloomustada midagi, mis muutub, millele on antud varasemast teistsugune suund, teine sisu (10).

(10) Humanitaarteadused pöördes; elu on ühtäkki sootuks pea peal ja elanikud täiega pöördes.

Kui keha või õhu, vee füüsiliselt liikumiselt teha ülekanne mentaalsesse emotsioonide valdkonda, siis märgivad pöördes, pyörteessä, pyörryksissä ebatavaliselt intensiivset emotsionaalset seisundit, s.o vaimustuses, joovastuses, ekstaasis, tugevasti sisse võetud olemist (vt 14). Samatüveliste eesti ja soome lekseemide otsetähendused on küll erinevad, kuid üksteisega selgelt seotud: pööre 'ühekordne pöördumine ümber telje v. keskpunkti; enese keha v. sõiduriista pööramine, selle asendi v. suuna muutmine, kääne’ (EKSS); pyörre 'pööris, keeris' (MOT, SES); pyörryksissä, pyörryksiin 'pea käib ringi, pea pööritab', pyörryksistä 'minestusest toibumas' (MOT, SES). Seetõttu lähtub nende mõistmine kujundlikena ühtedest ja samadest mõistemetafooridest EBATAVALINE ASENDIMUUTUS

\footnotetext{
$5 \quad$ Kasutavad põhilisel noored, kuid mõjub vananenult (SS).
} 
ON SÜNDMUSTE VÕi EMOTSIOONIDE INTENSIIVNE KULGEMINE (vt vastavalt näide 11 ja 12) ja EBATAVALINE ASEND ON EBATAVALINE SEISUND (13).

(11) Joutui mukaan tapahtumien pyörteeseen, vrd jäi kadunuks rahutute aegade keerises; Pyörteessä päivien keskellä.

(12) joutui pyörteeseen; Lyödä joku pyörryksiin; Mees on sajaga pöördes; Olla onnesta pyörryksissä; tiinerid pöördes, saalid umbes; Liidellä tanssin pyörteissä.

(13) Puhua joku pyörryksiin 'kedagi oma jutuga surnuks rääkima' (MOT, SES); pyörteessä 'purjus' (US), vrd ära pöörama 'ebamõistlikuks muutuma, lolliks minema', vrd ka Ta armastab ikka vinti üle keerata 'liialdada', Viinast vintis seltskond (EKSS).

\subsubsection{Metafoorne liitsõna, mis on semantiliselt seotud polüseemiliste üksiksõnadega}

Kummitempel tähendab 'manipuleeritav, mõtlemisvõimetu täidesaatev asutus või selle liikmeskonda esindav instants'. Tempel on dokumentide ehtsuse tõendamise, millegi märgistamise vahend: kummitempel, metalltempel. Metafoori allikala oluline omadus elastsus tõstab esile sihtala spetsiifilise omaduse manipuleeritavuse. Metafoorses tähenduses kummitemplit hakati eesti keeles aktiivselt kasutama riigikogu iseloomustamiseks 2007. a: Kas riigikogu on kummitempel, millest ei sõltu suurt midagi?

Konventsionaalsete mõistemetafooride mitmekülgne, kuid püsiv loomus soosib nii uudsete metafoorsete keelendite arenemist, kasutusala laienemist kui ka järkjärgulist kinnistumist. Kummitempel 'käsutäitja, käsualuse, käsutäitliku või kuuleka alama, tallaaluse’ tähenduses on nüüd juba õige sage (14).

(14) Kohus ei ole kummitempel prokuröri käes; Onko Jyväskylän valtuusto pelkkä kumileimasin?; ühiskond muutub kummitempliks, mille peamine ülesanne on olla kätte võidetud heaolu pitsatiks. 


\subsubsection{Metafoorsed sõnaühendid, mis on semantiliselt seotud fraseologismidega}

Lauda puhtaks lööma, laud on puhas paistavad olevat seotud eesti fraseologismidega platsi puhtaks lööma, plats on puhas. Sündmuse toimumise kohta mõistemetafoori allikalas tähistab nüüd platsile visuaalselt sarnane laud. Selle tulemuseks on tähenduse 'otsustavalt ära, minema ajama', 'otsustavalt ära, minema aetud' uudne keelendus (15).

(15) Selle asemel, et lï̈a pärast valimisi laud puhtaks, vrd Uusi elämä ja puhdas pöytä; Loman jälkeen halutaan ehkä aloittaa puhtaalta pöydältä.

Laiemas plaanis motiveerib kõigi nende sõnaühendite tähendust mõistemetafoor TÜHI või EELNEVATA, EELTEADMISTETA ON PUHAS. Leksikaalse teisenemisega kaasneb semantiline laienemine - füüsiline tühjendamine, äraajamine üldistub mentaalseks: 'oskuste vms poolest parem lükkab teised oma eduteelt kõrvale'. Tähendusmuutust võib olla motiveerinud ka mõistemetafoor INIMTEGEVUS või võISTLUS ON (KAARDI)MÄNG (vt näide 19), vrd liüiakse üks põhilisi trumpe lauale hinda tutvustades.

(16) muusikaauhindadel laua puhtaks löönud popstaar; Pöytä puhtaaksi konkurssissa; Primakov löisi laudalta kaikki muut poliitikot; Yleisömäärissähän kulttuuri lyö urheilun laudalta; Missä on kepun puhdas pöytä?.

Eesti meediatekstidest võib leida üksikuid näiteid samas tähenduses platsi puhtaks lööma kohta: lõi [laskesuusatajate] tulevikulootuste seas platsi puhtaks.

Nael kirstu. Idiomaatiline kirstunael tähistab inimesest või olukorda, kes või mis põhjustab suuri pahandusi, rohkesti muret, meelehärmi, südamevalu. Paistab, et üsna hiljuti on see liitnimisõna läbi teinud morfosüntaktilise teisenemise ning eesti keeles on käibele tulnud naela [kellegi või millegi] kirstu lööma, vrd ka inglise ja vene keeles (17).

(17) the final nail in the coffin; Кому выгодно вбить последний гвоздв в гроб отечественного кино. 
Liitsõna kirstunael täidab lauses tüüpiliselt nimisõnalise öeldistäite ülesannet iseloomustades-liigitades alust: Pennu kirstunael on kinnisvaraäri, kuigi päris tavaline on kirstunael ka aluse funktsioonis: Maksureformist saab valitsuse kirstunael. Olema-verbi ja öeldistäidet sisaldavad laused tähistavad staatilisi, s.o homogeenseid, pidevaid ja muutumatuid situatsioone. (EKG II: 57, 22 jj.) Vajadusest kasutada kujundit ka dünaamiliste situatsioonide puhul on staatiline predikaat asendatud dünaamilisega (18).

(18) Viimane nael erakonna ja ta paljastuste kirstu; Viimeinen naula vasemmiston arkussa?; Iga mure lööb me kirstu uue naela juurde; Eesti libarahvuslased kannavad missiooni lï̈ia Eesti riigi ja rahva kirstu kaane sisse viimane nael; Erän puolivälissä lyötiin viimeinen naula arkkuun; Et mitte olla uue naela kirstu lööjaks ..; [Jalgpallur] Matiaz tagus sloveenlaste hõisete saatel eestlaste kirstu kolmanda naela; Maalisvaaleissa saatetaan naulata viimeinen naula SMP:n arkkuun (SS); tilaisuus lyödä lopullinen niitti (SS).

Sõnaühendi tempel otsa ees osise tempel üks tähendusi on 'jäljend, jälg, märk. Nii tõstab metafoori allikala esile sihtala INIMENE karakteristiku 'millestki halvast märgistatud, halva kuulsusega' (19).

(19) Rahapuuduses vaevlemine on sul kui tempel otsa ees; 50+ on leima työttömän otsassa. Tal oli tempel otsa ees - Siberist tulnuna oli ta "nevõjezdnoi"; Idaeurooplase tempel otsa ees; Minulla on hullun leima otsassa.

Seega ei kujuta tempel otsa ees endast muud kui juba olemas olevate mõistemetafooride MENTAALNE OMADUS ON FÜÜSILINE TUNNUS ja HALB ON MUST, TUME, MÄÄRDUNUD järjekordset ilmingut, täpsemalt MÄRGI, PLEKI vmt süstemaatilist lisandust, vrd (20).

(20) Ka alusetust laimust võib inimesele märk külge jä̈̈da (EKSS); Kaini märk on otsa ees 'reeturi, tapja maine'; Juuda märk küljes 'reeturi maine'; See inimene otsib igaühe minevikust plekke (EKSS); häbimärgiga; häbi musta tumeda plekiga. 
Analüüs näitab, et metafoori kasutusel olnud osad ja nende laiendused on üksteisega küll süsteemselt seotud, kuid keelendite uus tähendus ei ole tuletatav varasemast.

\subsection{Metafoori kasutamata osade rakendamine}

\subsubsection{Metafoorsed üksiksõnad ja sõnavormid}

Puudel. Väga tihti on mõistemetafoori allikaks LOOMAD, LINNUd, mistõttu võib nende motiveeritud tähendusega keelendite arenemist kohati ettegi ennustada, vrd (21).

(21) Kremli lõukoer Naši läheb varjusurma; Lükkab alalõuga ette ja teeb sellist nö buldogi nägu.

Puudli kui lemmiklooma omaduste (peetakse ilu või moe pärast) ümbermõtestamise tulemusena märgib see iseseisvusetuid, teiste poolt juhitavaid, teiste tahet täitvaid inimesi (22).

(22) partei ei ole Tallinna koalitsioonis enam isegi mitte puudel, vrd ka Ära vali sülekoera, vali iseseisev politik; Median tehtävä on olla vallan vahtikoira eikä vallanpitäjien sylikoira.

Erinevalt eesti keelest võidakse lekseemi villakoira 'puudel' soome keeles kasutada ka hoopis teiselaadse tähenduse 'asja uba' (SES) keelendamisel: Akvaarioharrastuksessa villakoiran ydin on ekologinen opetus (SS).

Noor üleolev, ülbe, tähtsa olemisega, suureline, iseteadev tüüp, eriti poliitikas, on broiler (23).

(23) broiler riigimeheks; nädala broiler; Annab peale polittbroilerite nimekirja ka ülevaate broilerite hingehädast; 24-vuotias tuore puheenjohtaja ei pelkää polittisen broilerin leimaa.

Meie mõistesüsteemile on omane mõelda tähtsust täis inimesest kui täispuhutud või täissöönud tegelasest, vrd paksud 'ülemused'; lai pomm. Ilmselt on poliit- poliitiline broiler, sülekoer, puudel eesti keeles levima hakanud soome keele eeskujul. Politttinen broileri tähendab 'eluvõõras 
noor karjääripoliitik' (SES); broileri halvustavalt või naljatlevalt 'noor karjääripoliitik' (SS, SES), 'tähelennuga poliitik', 'kutseline poliitik' (SS). Seega on fraasi kasutusväli eesti ja soome keeles aja jooksul ühtlustunud.

\subsubsection{Metafoorsed sõnaühendid, mis on semantiliselt seotud polüseemiliste üksiksõnadega}

Rong on läinud, rongilt maas sisaldavad polüseemilisi verbe minema, maha jääma. Sõnaühendid tähendavad vastavalt '[keegi] ei ole suutnud, tahtnud või osanud millegi õiget aega kasutada,' '[keegi] on õige aja mööda lasknud, maha maganud' (24).

(24) Tulude deklareerimise rong pole veel lóplikult läinud; Kinnisvarainvestor arvas, et pehme maandumise rong on läinud.

Keelendite metafoorne tähendus on motiveeritud mõistemetafooridest MUUTUS ON LIIKUMINE, PROGRESS ja ARENEMINE ON EDASILIIKUMINE (vt selle kohta eesti keeles K. Õim \& A. Õim 2010). Rong kui transpordivahend soodustab progressi; sellega kattub osaliselt mõiste MASIN, mis tekitab kujutluse mehhaniseeritud transpordivahendist kui arengumudelist (vt Langlotz 2006: 161). Liikumis- või veovahend on eesti keeles elu tähistavate fraseologismide juures tüüpiline metafoori allikala (25).

(25) eluvanker -ratas; Kuidas eluregi jookseb?; sedasama kelku vedama (FES).

Traditsiooniliste ree-, kelgu-, vankri-, rattakujundite puhul peetakse silmas veovahendit ja selle olemuslikku liikumist. Tuues esile liikumise kvaliteeti suhestatakse omavahel veovahend ning mentaalsed ning sotsiaalsed mõisted: Noored inimesed, rattad kerged. Vana oled, siis on regi raske (FES). Rongi puhul on fookuses selle ajaliselt täpne lähe. Kui sellega ei arvestata, jääb eesmärk täitmata (26).

(26) ei suutnud meeskond teha enam midagi ning nende rong oli läinud 'kaotasid'; Turha huutaa, Nokian Android-juna meni jo; Jälgides metsiku looduse taandumist globaalselt, tuleb paratamatult tunne, et 
olemegi juba rongilt maas; Microsoft on pudonnut junasta, vrd ka koulussa osalla oppilaista on vaara pudota kunnolla kelkasta; tietotekniikka viuhtoo eteenpäin yhä kiihtyvää vauhtia - aktiivinenkin seniori meinaa pudota kyydistä; Maa myöhästyi EU-junasta (MOT).

Transpordivahendite arenemine koos uute kasutusevõtuga hõlbustab ja kiirendab liikumist ning loomuldasa kajastub see metafoorses keeles. Selle üle, miks olemasolevat temaatilist kujundirida on täiendatud just rongiga, võib vaid oletada. Võimalik, et sõna rong on tundunud ajakohasem kui näiteks sõit. Vrd sõit van 'raudteerong': Pärastlõunase sõidu pealt tulnud reisijad; Lokerdasime selle hirmsa sõiduga [= kaubarongiga] (EKSS), kyyti 'küüt, sõit': jäädä kyydistä 'sõidust rongist maha jääma' (SES) ja küüt 'edasiviimine, vedamine, küütimine': Kohvrite ja muu koli küïdiks hangiti käru (EKSS).

\subsubsection{Metafoorne sõnaühend, mis on semantiliselt seotud fraseologismidega}

Viimase peal. Fraseologismide viimase veerandi peal, viimase tuhande peal kujundi tuumaks on viimane. See omadussõna tähendab 'vahetult mingile kriitilisele piirile eelnev; selline, mis põhjustab mingi kvalitatiivse muutuse; äärmine' ning nimetatud fraasid tähendavad 'kriitilises seisus, otsakorral, lõppemas, läbi kulumas'. Veerand ja tuhat osutavad sellele, et millegi piirmäär ei ole veel saavutatud. On loogiline, et piirmäära markerite kõrvalejätmisega kaasneb tähendusmuutus. Eesti fraseoloogias on tavaline, et mõistemetafoori kasutamata osade rakendamine päädib fraseologismi leksikaalse laienemisega, vrd nt käed on kinni tähendustes 'saamatu, aeglane', 'hõivatud' - käed on kõhus kinni 'saamatu, aeglane' - käed on süles kinni 'naine väikese lapsega hõivatud'. Olles motiveeritud mõistemetafooridest VÄGA INTENSIIVNE ON FÜÜsILISELT ÄÄRMINE ja MENTAALNE INTENSIIVUS ON FÜÜSILINE ÄÄRMUS ei tähista võimalik soome laen viimase peal enam piirmäärale eelnevat seisundit, vaid piirmäära saavutamist, kvalitatiivse muutuse tulemust, kusjuures sellele antakse positiivne hinnang 'parim, väga hea, suurepärane' 
vms, vrd viimeisen päälle tähenduses 'läbinisti, täielikult' (SS). Lauses kasutatakse viimase peal ja viimeisen päälle küll üsna ühtemoodi (27).

(27) Metsavenna talus on nü̈d rajamasin ja viimase peal rajad; Viimeisen päälle poliisi; viimase peal uus sügis-talve mantel; Viimeisen päälle boheemi hippi; Ühissõidukite piletihinnad on seal viimase peal 'väga soodsad'; Kaikki on viimeisen päälle mietittyä (SS); Pienetkin yksityiskohdat on suunniteltu viimeisen päälle tarkasti (SS).

Vrd ka elää kuin viimeistä päivää 'elupõletajalikku elu elama, endale piiranguid seadmata elama' (SS):

(28) Ainakin rauhan tultua elettiin kuin viimeistä päivää; Ela iga päev nii, nagu see oleks su viimane!

Kirjeldatu ei hõlma sugugi mitte kõiki võimalusi, sest eespool nimetatud suundumused kombineeruvad omavahel. Näiteks on semantiline avardumine, polüseemilise tähenduse jätkuv areng omane ka idiomaatilistele fraasidele, vrd karvased ja sulelised tähendusi 'pikajuukseline, habetunud, karvadesse kasvanud nooruk' (EKSS) ja 'kõik, ükskõik kes' (29), 'ise; tervikuna, sellisena', 'täielikult' vm (30).

(29) Karvased ja sulelised valmistuvad Eurovisiooniks; hipid, titemammad, kodukanad, karjä̈rinaised, ühesõnaga karvased ja sulelised.

(30) Sitten kannatta vain hyväksyä itsensä sellaisena kuin on .. karvoineen ja sulkineen, pukinsorkkineen ja enkelin siipineen (NK); Kuntauudistusmrk reposteltava nahkoineen ja karvoineen (NK), vrd Kui sa ei tantsi tema pilli järgi, siis ta õgib su kõige naha ja karvadega (EKSS); Vastutad kõige naha ja karvadega (FES).

Metafoori kasutusel olevate osade laiendamisega on tegemist veel tädi Maali puhul. Võimalik, et 2000. aastate algul, kui käis Euroopa Liiduga ühinemise lahtirääkimine ja taheti väljendada vajadust teha see selgeks igale Eesti kodanikule, ei tundunud miski olemasolev küllalt lööv. Kui president Lennart Meri ütles, et Euroopa Liiduga ühinemisest tuleb rääkida nii, et ka tädi Maali aru saaks, oligi osava mõistestaja fantaasia ja pärisnime kaasamise tulemusena sündinud uus keelend, mis kujunes kiiresti lihtkodanike ühisnimetajaks. Kasutussageduse tõttu on kujundi 
tähendusmaht avardunud hõlmates mitte ainult lihtsakoelise mõtlemise ja eluga mitte kursis olevat inimest, vaid ka (tehniliste) teadmisteta, võhiklikku inimest (31):

(31) Tunnen ennast praegu tõelise tädi Maalina; Korvpallist kõneldi nädalavahtusel igast torust, lausa tädi Maali tasemel, vrd Tunnetuin seniorikansalainen lienee Pihtiputaan mummo ${ }^{6}$; niin selkeästi, että Pihtiputaan mummokin ymmärtää tekstin; vrd ka Kas need onu Heinod ise ka aru saavad, et nad onu Heinod on?

Tädi Maali kujund võib rajaneda teadmisel, et tädi on keegi võõras vanem naine, ning põhineda eeldusel, et vanemad naised ei ole suure tõenäosusega kuigi mõtlemis- ega arutlusvõimelised, vrd Pole ta nii tädi veel midagi! (EKSS, vt ka kukkahattutäti allpool). Lähedasel soome fraasil Pihtiputaan mummo on ka positiivseid konnotatsioone, sest seondub soome rahvusluse ja maanaiste tublidusega ${ }^{7}$.

Samuti ühiskondlik-poliitilises kontekstis kasutatava kampsunid tähenduse aluseks on metonüümiline ülekanne rühma inimeste tunnusliku riietuse alusel, kuid selle mõistestuses võidakse rakendada ka metafoori kasutamata osi ja MAAILMAVAATE JAGAMINE ON RIIDEESEME KANDMINE (32).

(32) Vanad isamaaliitlased ehk n.ö kampsunid sobiksid hästi maameeste parteisse, vrd paljuski sarnase tekkemehhanismiga fraasi omad joped tähenduses 'sarnase mõttelaadi ja eluhoiakuga inimesed, mõttekaaslased, semud': kompromissitus kaob, kui sekeldustesse satuvad omad joped, vrd ka Eliitti haluaa omat miehet valvomaan yleä; Rikollisjärjestöt haluavat "omia miehiä" valtarakenteisiin.

Algselt neutraalse nimetuse mõistestamisse on hiljem kaasatud kampsuni kui riietuseseme võimalikud tunnused (tavaline ja hinnatud, vastupidav, sageli rahvusliku mustriga, pidevast kandmisest kulunud,

$6 \quad$ 1960-ndate alguses sündinud väljendi autor on ajakirjanik A. Liuhala.

$7 \quad$ Kesk-Soome vallas nimega Pihtipudas on 1994. a alates vanaemadele välja antud Pihtiputaan mummo tiitlit, vrd Viis maakonna memme kandidaati pidid saali ees läbi tegema kujuteldava arstivisiidi. 
välja veninud jms), seega KONSERVATIIVNE ON TAVALINE, IGAPÄEVANE, VASTUPIDAV; MENTAALSELT AEGUNUD, MITTEAJAKOHANE ON FÜÜSILISELT KULUNUD (33).

(33) uut parteid need ärapeetud kampsunid ei loo; see teeb meist kampsunid, et me mõistame rahvuslust kui ühte kõige levinumat ideoloogiat, vrd Nyt kukkahattutädit haluavat kieltää tupakan mainostuksen, kus kukkahattutäti tähendab 'konservatiivne, uuenduskartlik, vähese otsustusvõimega naispoliitik' (US).

Kuna nimisõnaga kampsunid peetakse silmas konkreetsete inimeste kogumit, siis on selle morfosüntaktilised omadused piiratud ja kasutuses domineerib mitmuslik vorm, ainsust võib leida harva: Kampsun Vahtre sõnavara. Keelendi leksikaliseerumist võib pidurdada nimetatud mõistemetafooride liiga kitsas rakendusala ning arvatavasti taandub kampsunid koos isamaaliitlaste erakonnast lahku löömise ideedega. Sihtala laienemise korral näiteks nii, et see hõlmaks rahvuslikult meelestatud radikaale üldiselt, oleks leksikaliseerumine tõenäolisem.

Sellise uudse metafoorse keelendi tähendus, mis rajaneb mõistealade vahelisel uudsel ülekandel, on olemasolevate samakujuliste või lähedaste leksikoniüksuste suhtes homonüümne, näiteks nagu metonüümiline küüslaugu-. Seda ei motiveeri mitte küüslaugu kui taime teatavad spetsiifilised (paljudele ebameeldivad lõhna- ja maitse)omadused, vaid siin on süNDMUSKOHA TUNNUS (koht, kus peeti 2005. a läbirääkimisi Eesti valitsuskoalitsiooni moodustamiseks - küüslaugurestoran Balthasar) SÜNDMUSE ASEMEL. Just seetõttu puudus liitsõnas küüslauguliit jmt esialgu hinnang tekkinud liidule (34).

(34) hilisõhtuks suutsid küüslauguliidu osapooled ära jagada uue valitsuse ministrikohad, vrd Jääkeldrialgatus 'presidendi kokku kutsutud vabakonna esindajate, poliitikute jt arutelu toimumise koht' ja Eesti Rahva Muuseumi Raadil asuvas jääkeldris andsid ehituslepingule digiallkirjad .. , vrd ka Eteläranta kymppi 'US: Helsingis Eteläranta 10 asuv tööandjate institutsioon'.

Küüslauk kui maitse- ja ravimtaim kaasati metafoori allikalana mõistestamisse hiljem. Vastavalt keelekasutajate lõhna- ja maitseeelistustele 
tekkis hulk hinnangulisi keelendeid nii koalitsiooni enda, selle osapoolte kui ka üksikpoliitikute märkimiseks: Küüslaugukoalitsioon - see tähendab ju, et läheb hirmsasti haisema. Kuna primaarne küüslaugu-metafoor paistab olevat meile võõras (kuigi vrd Justkui sibul kõlbab iga toidu juure, oskab mitmesugust tööd (FES)), siis ei ole need mõnda aega aktiivses kasutuses olnud keelendid püsima jäänud. Nad hääbusid koos tähistatava - koalitsiooni lagunemisega. Nii ei ole küüslaugu-lekseemist saanud millise tahes erineva maailmavaatega osapoolte ebaõnnestunud (võimu) liidu tähistajat.

Analüüsitud keelendite tähendus on kokku võetud tabelis 2 .

TABEL 2. Uudsete metafoorsete keelendite tähendus

\begin{tabular}{|l|l|l|}
\hline \multicolumn{1}{|c|}{ mõiste } & \multicolumn{1}{|c|}{$\begin{array}{c}\text { üksiksõna(vorm) } \\
\text { või fraas }\end{array}$} & \multicolumn{1}{c|}{ metafoorne tähendus } \\
\hline \multirow{2}{*}{ RONG } & rong on läinud & 'õige, sobiv aeg on jäänud kasutamata' \\
\cline { 2 - 3 } rongilt maas & 'õige, sobiv aeg on jäetud kasutamata' \\
\hline \multirow{2}{*}{ LAUD } & lauda puhtaks lööma & 'otsustavalt ära, minema ajama' \\
\cline { 2 - 3 } & laud on puhas & 'otsustavalt ära, minema aetud' \\
\hline \multirow{2}{*}{ tempel otsa ees } & $\begin{array}{l}\text { 'millestki halvast märgistatud, halva } \\
\text { kuulsusega' }\end{array}$ \\
\cline { 2 - 3 } & kummitempel & $\begin{array}{l}\text { 'manipuleeritav, mõtlemisvõimetu } \\
\text { käsutäitja' }\end{array}$ \\
\hline PUUDEL & nael kirstu & $\begin{array}{l}\text { 'ebameeldiv sündmus, kahjulik tegu, } \\
\text { hoop' }\end{array}$ \\
\hline BROILER & broiler & 'iseseisvusetu inimene, teiste tahte täitja' \\
\hline SIGA & siga & 'noor üleolev karjääripoliitik' \\
\hline KUUM & kuum & $\begin{array}{l}\text { 'väga, kangesti, kõvasti, äärmiselt, hirm- } \\
\text { sasti' }\end{array}$ \\
\hline PÖÖRE & pöördes & $\begin{array}{l}\text { 'aktuaalne, tähtis või kiiret lahendust } \\
\text { nõudev' }\end{array}$ \\
\hline VIIMANE & viimase peal & 'vaimustuses, joovastuses, ekstaasis' \\
\hline
\end{tabular}




\section{Kokkuvõte ja järeldused}

Uudsete keelenditega, mida ei ole ÕS-is ega EKSS-is metafoorses tähenduses fikseeritud, tähistatakse kas uusi mõisteid või pakuvad nad olemasolevate väljendusvõimaluste kõrvale uusi, täpsemaid, isikupäraseid, epateerivaid. Keele loomuliku osana on uudsete metafoorsete keelendite kasutussagedus eesti argikeeles märkimisväärne, mistõttu on nad väärt uurimist.

Piiratud hulga, 13 mittekonventsionaalse keelendi analüüs näitab, et nende mõistmine toetub sageli ja loomuldasa inimlikule argisele mõistesüsteemile, mis on konventsionaalne, suuresti metafoorne ja keeleülene. Usutavasti ei tule enamik uusi, ka laenulisi metafoorseid keelendeid keelde kontseptuaalses plaanis sugugi tühjale kohale - nende puhul võib olla tegu konventsionaalsete mõistemetafooride järjekordse ilmnemisega keeles, mida juhib üldistamine ja millega on seletatav ka keelendite elujõulisus. Selle asemel, et luua mõistealade mõistete vahel teadlikult täiesti uusi vastavusi, laiendatakse pigem metafoorsete mõistete kasutusel olevaid osi või rakendatakse metafoorsete mõistete seni kasutamata elemente. Kõik analüüsitud keelendid on mõisteseoseid pidi semantiliselt seotud eesti (ja soome) keeles olemasolevate leksikoniüksustega. Viimastega võrreldes on uudsete keelendite tähenduses märgata erinevusi, mis võivad olla markeeritud ka leksikaalselt ja/või morfosüntaktiliselt. Selgub, et 1) tänapäeva eesti keele polüseemiline üksiksõna avardub semantiliselt; 2) polüseemilise üksiksõna ümber tekkiv fraas on selle üksiksõnaga võrreldes semantiliselt kitsam; 3) fraseologism ja uudne metafoorne sõnaühend on üksteise suhtes leksikaalsemantilised variandid. Nähtavasti on polüseemilisel sõnal diakrooniliselt suurem soodumus metafoorseteks tähendusteks kui monoseemilisel sõnal.

See, kas käsitletud uudsed keelendid edaspidi eesti kirjakeeles kinnistuvad, sõltub mh keelevälistest teguritest. Eespool selgitasime, et enamik neist ühildub meie metafoorselt liigendatud mõistete süsteemiga. Kui keeleüksuste referendid jäävad püsima, siis suure tõenäosusega kinnistuvad nad keelekasutuses ning neil on eeldusi saada leksikoni 
osaks - nad konventsionaliseeruvad leksikoni tasandil. Pea kõigi analüüsitud uudsete keelendite osiste semantikas on toimunud sisemine liigendumine. Nende muutuste mõjul on eesti argikeeles käibel suur hulk metafoorseid keelendeid, mis on praegu sotsialiseerumisjärgus, erinevalt soome keelest on vaid mõni üksik neist jõudnud sõnaraamatusse näitetasandil.

\section{Tänusõnad}

Artikkel on valminud Eesti Teadusfondi grandi nr 8222 "Ülekantud tähenduses fraasid eesti keele korpustes" raames.

\section{Materjali allikad}

Eesti Keele Instituudi tekstikorpus. http://portaal.eki.ee/corpus (26.11.2012).

EKSS $=$ Langemets, Margit, Mai Tiits, Tiia Valdre, Leidi Veskis, Ülle Viks, Piret Voll (Toim.) 2009. Eesti kirjakeele seletussõnaraamat I-VI. Eesti Keele Instituut. Tallinn: Eesti Keele Sihtasutus. http:/www.eki.ee/dict/ekss (26.11.2012).

FES = Õim, Asta, Katre Õim 2011. Eesti fraseologismide elektrooniline alussõnastik. http:/www.folklore.ee/justkui/sonastik (26.11.2012).

SES = Haak, Anu, Paul Kokla, Külli Kuusk, Helga Laanpere 2003. Soome-eesti suursõnaraamat. Suomi-viro-suursanakirja. Valdek Pall (Toim.). TallinnHelsinki: Eesti Keele Sihtasutus, Kotimaisten kielten tutkimuskeskus.

MOT $=$ Kielitoimiston sanakirja 2012. Kotimaisten kielten keskuksen julkaisuja 166. Helsinki: Kotimaisten kielten keskus ja Kielikone. http://www.kielikone.fi/fi/tuotesivu/?intProductID=394 (26.11.2012).

NK = Kari, Erkki 1993. Naulan kantaan. Nykysuomen idiomisanakirja. Helsinki: Otava.

SS = Muikku-Werner, Pirkko, Jarmo Harri Jantunen, Ossi Kokko 2008. Suurella sydämellä ihan sikana. Suomen kielen kuvaileva fraasisanakirja. Jyväskylä: Gummerus.

US = Urbaani sanakirja. http://urbaanisanakirja.com (26.11.2012).

Wiedemann $=$ Wiedemann, Ferdinand Johann 1973. Eesti-saksa sõnaraamat. Neljas, muutmata trükk teisest, Jakob Hurda redigeeritud väljaandest. Tallinn: Valgus. 
ÕS = Erelt, Tiiu, Tiina Leemets, Sirje Mäearu, Maire Raadik 2006. Eesti õigekeelsussõnaraamat. Tiiu Erelt (Toim.). Eesti Keele Instituut. Tallinn: Eesti Keele Sihtasutus. http:/www.eki.ee/dict/qs (26.11.2012).

\section{Kirjandus}

Ammon, Ulrich 2002. Deutsch unter Druck von Englisch. Deutsch-EnglischEuropäisch. Impulse für neue Sprachpolitik. Rudolf Hoberg (Hrsg.). Mannheim; Leipzig; Wien; Zürich: Dudenverlag, 131-151.

Билибин, Д. Д. 2009а. Новые метафоры - символ объединенной Европы. Известия Российского государственного педагогического университета им. А. И. Герцена: Общественные и гуманитарные науки 12 (89). СПб., 224-227.

Bilibin, Dmitri 2009b. Das metaphorische Europa. Der Einfluss des EUIntegrationsprozesses auf die deutsche Sprache. - Материалы совместного научно-исследовательского проекта по германистике РГПУ им. Герцена и Берлинского университета им. Гумбольдта. СПб.: Изд-во Политехн. Ун-та, 116-122.

Brandstetter, Gerfried 1995. Euro-ABC: Lexikon der wichtigsten EU-Abkürzungen und Initialwörter. Wien: Wirtschaftsverl. Ueberreuter.

Croft, William, D. Alan Cruse 2010 [2004]. Cognitive Linguistics. Cambridge: Cambridge University Press.

Гацалова, Л. Б. 2005. Неология в современной лингвистике. Монография. Под ред. докт. фил. наук, проф. Р. С. Аликаева. Сев.-Осет. гос. ун-т. Владикавказ: Изд-во СОГУ.

Gibbs, Raymond W. Jr 2002 [1994]. The Poetics of Mind. Figurative Thought, Language, and Understanding. Cambridge: Cambridge University Press.

Gibbs, Raymond W. Jr 2007. Why cognitive linguists should care more about empirical methods. - M. Gonzalez-Marquez, I. Mittleberg, S. Coulson, M. Spivey (Eds.). Methods in Cognitive Linguistics. Amsterdam: John Benjamins, 2-18.

Greciano, George 2004. Fachtextphraseologie aus europäischer Perspektive. Wortverbindungen mehr oder weniger fest. Kathrin Steyer (Hrsg.). Berlin, New York: Moutonde Gruyter, 394-414.

EKG I = Erelt, Mati, Reet Kasik, Helle Metslang, Henno Rajandi, Kristiina Ross, Henn Saari, Kaja Tael, Silvi Vare 1995. Eesti keele grammatika I. Morfoloogia. Sõnamoodustus. Tallinn: Eesti Teaduste Akadeemia Eesti Keele Instituut. 
EKG II = Erelt, Mati; Reet Kasik, Helle Metslang, Henno Rajandi, Kristiina Ross, Henn Saari, Kaja Tael, Silvi Vare 1993. Eesti keele grammatika II. Süntaks. Lisa: Kiri. Tallinn: Eesti Teaduste Akadeemia Eesti Keele Instituut.

Erelt, Mati, Tiiu Erelt, Enn Veldi 2003. Eesti-inglise keeleteaduse sõnastik. Tallinn: Eesti Keele Sihtasutus.

Habicht, Külli, Pille Penjam 2007. Kaassõna keeleuurija ja -kasutaja käsituses. Emakeele Seltsi aastaraamat 52 (2006), 51-65.

Kasik, Reet 2003. Ajakirjanduskeel. - Eesti kirjakeele kasutusvaldkondade seisundi uuringud. Tallinn: TPÜ Kirjastus, 118-148.

Катаева, С. Г. 2003. Идеологически релевантная лексика в эпоху перемен. Вопросы лингвострановедения и лексикологии: межвуз. сб. ст., аннот., рец., библиогр. под ред. В. Д. Девкина. М.: Прометей, 67-76.

Клочко, Н. Н. 2006. Образы Европы в современных национальных дискурсах (на примере антропоморфной метафорики). - Современная политическая лингвистика. Екатеринбург: ГОУ ВПО Урал. гос. пед. ун-т, 213-226.

Krikmann, Arvo 1999. Vanasõnad loomade identiteedist (Tüpoloogilisi memuaare). - Mäetagused 12, 52- 86.

Krikmann, Arvo 2003. Kaasaegse metafooriteooria panus parömioloogiasse. Uurimusi folkloori lühivormidest. Reetor 1. Tartu: Eesti Kirjandusmuuseum. Folkloristika osakond. Eesti Kultuuriloo ja Folkloristika Keskus, $52-144$.

Kukk, Inga 2001. Eesti rahvuspoliitika osalised ajalehetekstides. Kriitiline tekstianalüüs. - Reet Kasik (Koost. ja toim.). Keele kannul. Pühendusteos M. Erelti 60. sünnipäevaks 12. märtsil 2001. Tartu Ülikooli eesti keele õppetooli toimetised 17. Tartu: Tartu Ülikool, 146-165.

Lakoff, George 2006 [1993]. The Contemporary Theory of Metaphor. - D. Geeraerts (Ed.). Cognitive Linguistics: Basic Readings. Berlin-New York: Mouton de Gruyter, 185-238.

Lakoff, George, Mark Johnson 1999. Philosophy in the Flesh: The Embodied Mind and Its Challenge to Western Thought. New York: Basic Books.

Lakoff, George, Mark Johnson 2011. Metafoorid, mille järgi me elame. Tallinn: TLÜ Kirjastus.

Lakoff, George, Mark Turner 1989. More than Cool Reason: A Field Guide to Poetic Metaphor. Chicago-London: The University of Chicago Press. http:// dx.doi.org/10.7208/chicago/9780226470986.001.0001 
Langlotz, Andreas 2006. Idiomatic Creativity: A Cognitive-Linguistic Model of Idiom-Representation and Idiom-Variation in English. Amsterdam/Philadelphia: John Benjamins.

Lotman, Mihhail 2011. Metafoorid ja elu. - Metafoorid, mille järgi me elame. Tallinn: TLÜ Kirjastus, 7-24.

Penttilä, Esa, Pirkko Muikku-Werner 2012. Domestication and foreignization in figurative idiom translation. - Marja Jänis, Hannu Kemppanen, Alexandra Belikova (Eds.). Domestication and Foreignization in Translation Studies. Berlin: Frank \& Timme, 121-138.

Попова, Т. В. 2005. Неология и неография современного русского языка. М.: Наука.

Raadik, Maire 2008. Võõrad võõrsõnad. - Maire Raadik (Koost. ja toim.). Keelenõuanne soovitab 4. Eesti Keele Instituut. Tallinn: Eesti Keele Sihtasutus, 43-63.

Rohtlaan, Ille 2006. Metafoorid meediatekstis: uudiste pealkirjad. - Keel ja Kirjandus 8, 626-636.

Schäffner Christina 1995. Metapher als Bezeichnungsübertragung? - Inge Pohl, Horst Ehrhardt (Hrsg.). Wort und Wortschatz: Beiträge zur Lexikologie. Tübingen: Niemeyer, 175-84.

Сенько, Е. В. 2007. Неологизация в современном русском языке: межуровневый аспект. М.: Наука.

Скуратов, И. В. 2006. Типологическая характеристика неологизмов в современном разговорном и деловом французском языке: лингвистический и социолингвистический аспекты. М.: МГОУ.

Steen, Gerard J., Aletta G. Dorst, J. Berenike Herrmann, Anna Kaal, Tina Krennmayr, Trijntje Pasma 2010. A Method for Linguistic Metaphor Identification. From MIP to MIPVU. Amsterdam/Philadelphia: John Benjamins.

Sweetser, Eve 1991. From Etymology to Pragmatics: Metaphorical and Cultural Aspects of Semantic Structure. Cambridge Studies in Linguistics 54. Cambridge: Cambridge University Press.

Zinken, Jöerg, Elena Bolotova 2006. Der Europäische Raum. Metaphernmodelle im russischen und im deutschen Diskurs zur Europäischen Integration. Kulturelle Vorstellungswelten in Metaphern. Metaphorische Stereotypen der deutschen und russischen Medien als Hypertext. Frankfurt a. M.: Peter Lang, 291-309.

Чудинов, А. П. 2001. Россия в метафорическом зеркале: когнитивное исследование политической метафоры (1991-2000). Екатеринбург: ГОУ ВПО Урал. гос. пед. Ун-т. 
Weinrich, Harald 2002. Europa Linguafrancaland? - Rudolf Hoberg (Hrsg.). Deutsch-Englisch-Europäisch. Impulse für neue Sprachpolitik. Mannheim, Leipzig, Wien, Zürich: Dudenverlag, 30-43.

Õim, Asta 2011. Komistusi metafooridega. Tartu: Keelehooldekeskus.

Õim, Katre, Asta Õim 2010. Qualitative Changes in Phraseology: General Principles and Catalysts. - Linguistica Uralica 46 (1), 17-37. http://dx.doi. org/10.3176/lu.2010.1.02

\section{Katre Õim}

Tallinna Ülikooli eesti keele ja kultuuri instituut

Narva mnt 29

10120 Tallinn, Estonia

katre.oim@tlu.ee

\section{Asta Õim}

Eesti Kirjandusmuuseum

Vanemuise 42

51003 Tartu, Estonia

asta.oim@gmail.com

\section{Pirkko Muikku-Werner}

Itä-Suomen yliopiston humanistinen osasto, suomen kieli ja kulttuuritieteet

PL 111

FI-80101 Joensuu, Finland

pirkko.muikku-werner@uef.fi 


\title{
Novel metaphorical linguistic forms: a loan or a result of diachronic development?
}

\author{
KATRE ÕIM \\ Tallinn University \\ ASTA ÕIM \\ Estonian Literary Museum \\ PIRKKO MUIKKU-WERNER \\ University of Eastern Finland
}

The paper explicates the meaning of novel metaphorical words, word forms and sets of words, demonstrates how these meanings are constructed, their salience in the lexicalization process, and their lexico-semantic relations with lexemes in Finnish. All the linguistic forms under discussion here are nonconventional on the one hand, but rely on the conventional human conceptual system and, thus, are related with the existing units in the Estonian lexicon, on the other. From the conceptual perspective, most of the new, among them borrowed, metaphorical linguistic forms have not sprung from nothing - instead, they might be yet another manifestation of conceptual metaphors, which is guided by generalization and which also explains why such words and phrases are so pervasive in language. Rather than consciously mapping completely new equivalences between conceptual domains, the more commonly used constituents of metaphorical concepts are expanded or the so far unused constituents of the metaphorical concepts are applied. Through conceptual links, all the analyzed linguistic forms are bound with the already existing units in the Estonian (and the Finnish) lexicon. Compared to the latter, there are noticeable differences in the meaning of the novel linguistic forms, which may carry either lexical or morpho-syntactic markings. The paper demonstrates that (1) a polysemic single word in modern Estonian expands semantically; (2) a phrase constructed around the polysemic single word is semantically 
narrower than the single word; and (3) the idiomatic expression and the novel metaphorical set of words are the lexico-semantic variants of each other.

Whether the novel linguistic forms under discussion will become established in Estonian written language depends, among other things, on extralinguistic factors. Should referents of the language units persist, then, very likely, they will become established in language usage and stand a good chance of becoming part of the lexicon. Almost all the novel linguistic forms under analysis here have a chance to become lexicalized in the Estonian language, since internal structuralization has taken place in the semantics of these constituents. As a result, spoken Estonian contains a number of such metaphorical linguistic forms undergoing socialization.

Keywords: cognitive linguistics; semantics; conceptual metaphor; novel metaphorical linguistic form; Estonian; Finnish 